\title{
PERANCANGAN INTERIOR BRIDAL BOUTIQUE DI BALI
}

\author{
Intan Sinta Lestari ${ }^{1}$, Ahmad Fajar Ariyanto ${ }^{2}$ \\ Program Studi S1-Desain Interior \\ Fakultas Seni Rupa dan Desain, Institut Seni Indonesia (ISI) Surakarta \\ 1Email: shin.intan@yahoo.com \\ 2Email: leahfajar@yahoo.com
}

\begin{abstract}
Marriage is a precious moment for everyone, which is expected to be once in a lifetime. In the implementation of marriage, the bride and groom expect perfection in their precious moments, the venue to be a matter of great concern. Bali is one of the destinations to hold weddings, because Bali is the number one tourist destination in Indonesia and offers natural beauty that makes travelers interested in vacationing and capturing their precious moments. So it is necessary to have a bridal boutique that functions to provide wedding needs with services and quality products that are quite complete such as national wedding gowns, international wedding gowns, party gowns, tuxedos, kid's gowns and tuxedos, accessories, invitation cards, souvenirs, photo studios, fittings room, make up, and consultation. Bridal Boutique in Bali carries the theme "La Femme Balinaise est Manifique" with a contemporary style, with the aim of presenting Balinese culture that is packaged in a modern feel, and it is hoped that users will feel comfortable, warm, prestigious, sacred, fancy, and fun when spending time in bridal boutique.
\end{abstract}

Keywords: bridal, boutique, shop, retail, bali.

\section{PENDAHULUAN}

Pernikahan merupakan suatu momen berharga bagi setiap orang, upacara sakral yang diharapkan sekali seumur hidup akan lebih bermakna dan berkesan ketika dipersiapkan dengan baik. Dewasa ini upacara pernikahan menjadi kebutuhan tersendiri bagi sebagian kelas sosial terutama mereka yang hidup di kota besar. Dalam pelaksanaan pernikahan, mempelai mengharapkan kesempurnaan dalam momen berharga mereka. Upacara pernikahan dipandang dapat menunjukkan strata sosial orang tersebut. Segala sesuatu dalam pernikahan harus dipersiapkan dengan matang, terutama yang bersangkutan dengan perlengkapan pernikahan seperti aksesoris, baju pengantin, buket bunga dan sebagainya, sehingga diperlukan adanya fasilitas yang mengakomodasi kebutuhan perlengkapan pernikahan yang disebut dengan bridal boutique. Salah satunya adalah bridal boutique di Bali.
Bali adalah primadona pariwisata Indonesia yang sudah terkenal di seluruh dunia dengan keindahan alam, selain itu Bali juga terkenal dengan kesenian dan budayanya yang unik dan menarik. Sehingga banyak orang menjadikan Bali sebagai pilihan untuk menyelenggarakan pernikahan dan mengabadikan momen berharga mereka di pulau dewata. Tidak sedikit wisatawan dari mancanegara yang melangsungkan pernikahan maupun pre-wedding di Bali. Perancangan bridal boutique di Bali bertujuan untuk mempermudah bagi calon pengantin maupun keluarga untuk memenuhi kebutuhan pernikahan.

Perancangan bridal boutique di Bali ini berada di Jalan Sunset Road, Seminyak, Kuta, Kabupaten Badung, Bali. Pertimbangan pemilihan area tersebut dikarenakan Jalan Sunset Road yang berada di Seminyak adalah kawasan elite yang memiliki banyak fasilitas publik. 
Perancangan interior Bridal Boutique di Bali mengusung tema "La Femme Balinaise est Magnifique" atau dalam Bahasa Indonesia berarti Kecantikan Perempuan Bali yang di kemas dalam gaya kontemporer. Gaya Kontemporer berarti gaya yang menunjukkan kekinian, sesuatu yang sama dengan kondisi waktu saat ini atau berkembang sesuai jaman sekarang. Ruang bergaya kontemporer memiliki kesan lebih dinamis dan segar, bentuknya bebas, modern, dan unik.

\section{Ide / Gagasan Perancangan}

a. Perancangan interior bridal boutique akan mengemas sebuah fasilitas kebutuhan pernikahan dalam satu tempat (one stop bridal ).

b. Merancang interior bridal boutique dengan tema "la femme balinaise est manifique" dalam gaya kontemporer.

\section{Metode Perancangan}

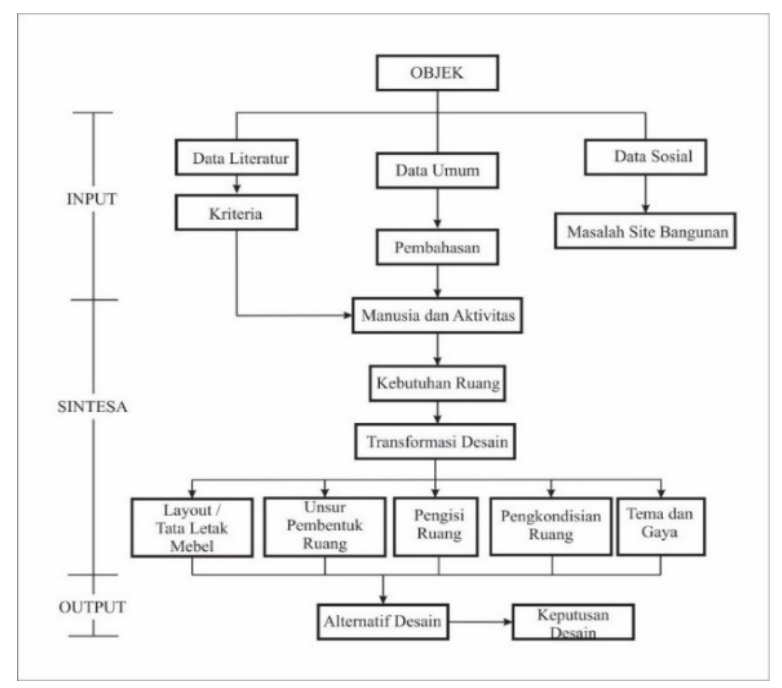

Gambar 1. Tahapan Proses Desain

(Pamudji Suptandar, Desain Interior. 1999. Hal 15)

Berdasarkan tahapan diatas proses desain diawali dengan pengumpulan data, yakni data lapangan dan data literatur. Data yang sudah terkumpul termasuk hasil wawancara akan digunakan sebagai acuan dalam penyusunan programming, pembuatan konsep desain dan aplikasi konsep desain dalam objek perancangan interior bridal boutique di Bali. Setelah itu masuk ke dalam tahap konsep perancangan untuk diterapkan kedalam objek perancangan. Desain tersebut akan melewati tahap pengembangan desain sebeum memasuki tahap desain akhir untuk mendapatkan akternatif desain terbaik.

\section{Landasan Perancangan}

Perancangan Interior Bridal Boutique di Bali terdiri atas lobby area, beauty area, retail area, fitting room, consultation area, dan office area, service area dan studio foto. Desainer interior harus mampu menyelesaikan permasalahan yang ditemukan saat pengumpulan data untuk dapat mengakomodasi kebutuhan pengguna sehingga merasa aman dan nyaman dalam beraktivitas. Dalam mewujudkannya diperlukan beberapa pendekatan pemecahan desain, fungsi pendekatan desain adalah untuk menganalisis, menemukan alternatif solusi desain, dan menghasilkan desain yang terbaik, di antaranya sebagai berikut:

\section{a. Pendekatan Fungsi}

Desain yang baik adalah desain yang memenuhi kebutuhan fungsi. Menurut Francis .D.K Ching, pendekatan fungsi yang sesuai kriteria meliputi:

1) Pengelompokan perabot berdasarkan fungsi,

2) Dimensi dan jarak yang sesuai,

3) Jarak sosial yang memadai,

4) Privasi visual dan akustik yang sesuai,

5) Fleksibilitas dan adaptabilitas yang memadai,

6) Sarana penerangan dan sarana elektris lainnya atau mekanis yang sesuai. 


\section{b. Pendekatan Ergonomi}

Ergonomi adalah ilmu yang mempelajari ilmu terapan yang berusaha untuk menyerasikan pekerja dengan lingkungan kerjanya atau sebaliknya, dengan tercapainya produktifitas dan efisiensi yang setinggi-tingginya melalui pemanfaatan manusia seoptimalnya. Sasaranergonomic adalahagartenaga kerja dapat mencapai prestasi kerja yang tinggi (produktif) tetapi dalam suasana yang aman dan nyaman.

Menurut Sunarmi pada dasarnya perancangan desain interior harus mampu menciptakan sarana untuk kepentingan manusia, sehingga ada beberapa unsur yang harus diperhatikan yaitu: aktivitas, kapasitas, dan anthropometri.

Dalam standardisasi antropometri, perancangan bridal boutique menggunakan standar ergonomi pada ruang retail. Menggunakan pertimbangan antopometrik untuk jarak bersih yang digunakan dalam pembuatan perancangan dasar. Daerah pandang yang tepat bagi tempat tempat untuk display baik dari arah dalam maupun dari arah luar juga sangat penting dalam keberhasilan perancangan sebuah ruang retail.

\section{c. Pendekatan Estetis}

Keindahan menjadi salah satu unsur yang harus diperhatikan dalam perancangan desain interior. Estetis atau Estetika pada dasarnya adalah sesuatu yang menyenangkan. Menurut Sokrates dalam buku Pengantar Estetika oleh Prof. Dharsono, pada dasarnya estetika adalah "suatu yang indah" atau "sesuatu yang indah" ialah yang menyenangkan.

Pendekatan estesis menurut prinsip-prinsip desain meliputi:

1) Skala ruang dan fungsi yang sesuai,

2) Pengelompokan visual kesatuan dengan variasi,

3) Interpretasi benda - dasarnya,

4) Komposisi 3-dimensi : Ritme, harmoni dan keseimbangan,
5) Orientasi yang tepat terhadap cahaya, pandangan, atau fokus internal,

6) Rupa, warna, tekstur dan pola.

d. Pendekatan Teknis

Pendekatan material pada perancangan ini tekait dengan pemilihan material atau bahan, teknik kontruksi dan finishing. Tiga hal tersebut harus dicapai, sehingga penulis dapat mengkomunikasikan bentuk yang di inginkan agar penciptaan tema pada perancangan tersampaikan.

\section{Batasan Ruang Lingkup Garap}

Ruang lingkup garap sebagai perwujudan interior dalam perancangan ini dibatasi pada perancangan;

a. Fasilitas Utama

1) Lobby Area sebagai tempat mendapatkan informasi dan sebagai pintu utama masuk ke dalam bridal boutique.

2) Retail Area sebagai tempat memajang produk sehingga konsumen bisa memilih dan membeli produk.

3) Beauty Area sebagai tempat untuk hair do dan make up

4) Fitting Room sebagai tempat untuk mecoba baju dan penngukuran

5) Consultation Area tempat dimana konsumen dapat berkonsultasi dengan desainer.

6) Studio Foto sebagai tempat untuk pengambilan gambar indoor.

a. Fasilitas Pendukung

1) Office

2) Repaired Area

3) Staff Room

4) Break Room

5) Control room

6) Lavatory

7) Storage (Gudang / Ruang Penyimpanan) 


\section{PEMBAHASAN}

Perancangan Interior bridal boutique di Bali merupakan salah satu alternatif toko kebutuhan pernikahan yang memberikan fasilitas yang cukup lengkap. Bali adalah tujuan wisata nomor satu di Indonesia menawarkan keindahan alam yang membuat pelancong tertarik untuk berlibur dan mengabadikan momen berharga mereka. Salah satunya banyak dari mereka melangsungkan foto pre-wedding maupun acara wedding party di pulau dewata. Melihat kebutuhan tersebut perancang ingin memfasilitasi mereka yang membutuhkan segala keperluan pernikahan di satu tempat. Tidak hanya itu, bridal boutique ini diharapkan menjadi pusat mode bridal yang berada di Bali maupun Indonesia.

\section{Tinjauan Data Literatur}

\section{a. Retail}

Ritel adalah rangkaian aktivitas bisnis yang memberi nilai tambah pada produk dan layanan yang dijual kepada konsumen end user atau pengguna akhir, bukan untuk dijual kembali, melainkan untuk penggunaan dan konsumsi oleh pembeli. Terdapat beberapa jenis-jenis retail diantaranya adalah department store, archade, convenience store, chain store dan boutique.

\section{b. Boutique}

Boutique merupakan Bahasa Perancis yang Bahasa Indonesia nya adalah butik. Butik merupakan gerai perbelanjaan kecil, terutama yang mengkhususkan diri dalam item busana yang elit dan fashionable yang dapat mencakup pakaian, aksesori dan perhiasan, serta merupakan suatu jenis usaha sebagai jembatan penghubung antara produsen pakaian dengan pembeli atau end user. Butik akan memudahkan dalam penjualan produk baju yang di beli, karena konsumen bebas memilih dan produk baju yang disediakan pun bisa dilihat dan dicoba, sehingga pembeli bisa be- nar-benar nyaman dengan produk yang dibeli.

\section{Site Plan}

Pemilihan lokasi berperan penting dalam sebuah perancangan. Lokasi yang ramai, strategis dan mudah di jangkau akan memudahkan calon pengunjung. Perencanaan lokasi yang tepat dapat menjadi penentu dalam keberhasilan dan kesuksesan sebuah usaha. Perancangan bridal boutique mengambil lokasi di Jalan Sunser Road, Seminyak, Kuta, Kab. Badung. Ini perupakan jalan utama yang menghubungkan hampir semua lokasi di bali. Berdekatan dengan airport, hotel bintang lima, mall, restoran, café, dan masih banyak lagi public space yang berada di Jalan Sunset Road ini menjadi dasar pertimbangan pemilihan lokasi dalam perancangan bridal boutiqu
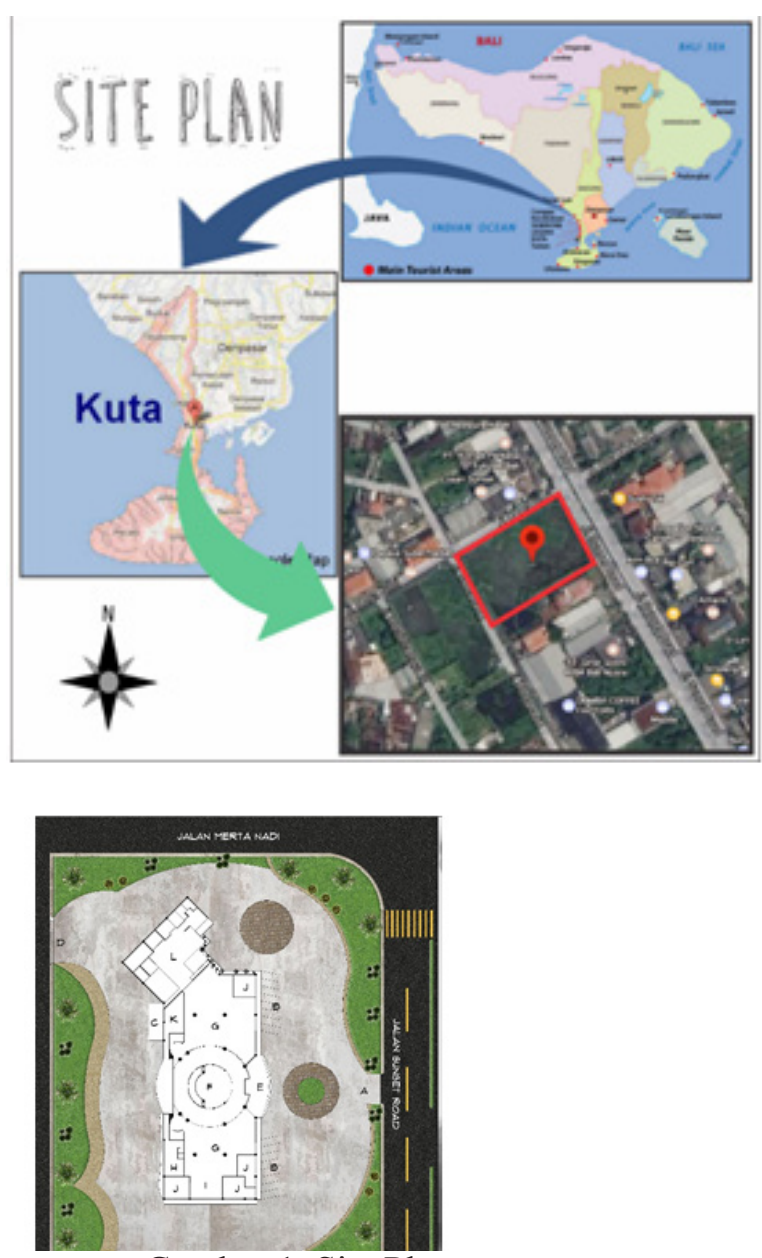

Gambar 1. Site Plan 


\section{Struktur Organisasi}

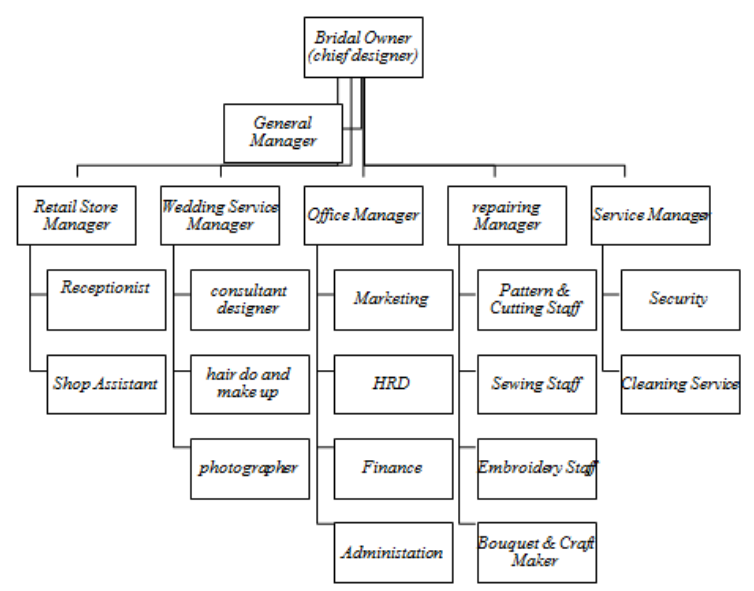

Skema 1. Struktur Organisasi

\section{Hubungan Antar Ruang}

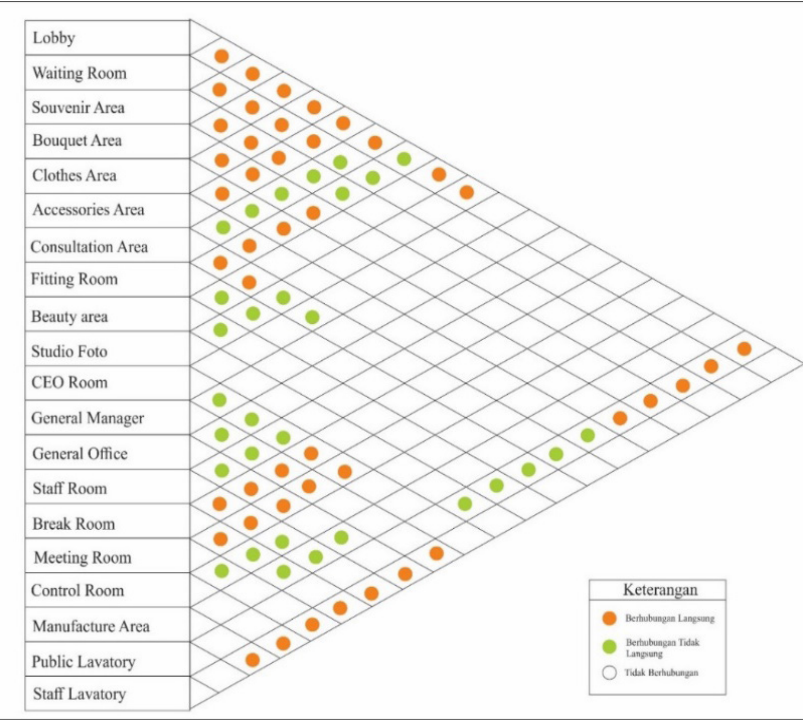

Skema 2. Hubungan Antar Ruang

\section{Grouping Zoing}

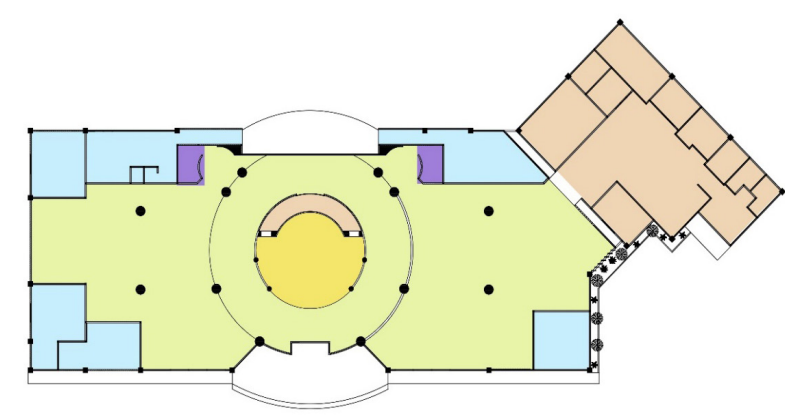

Keterangan :

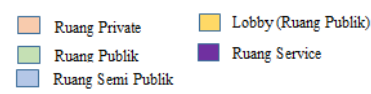

Gambar 3. Grouping dan Zoning

\section{Sirkulasi}

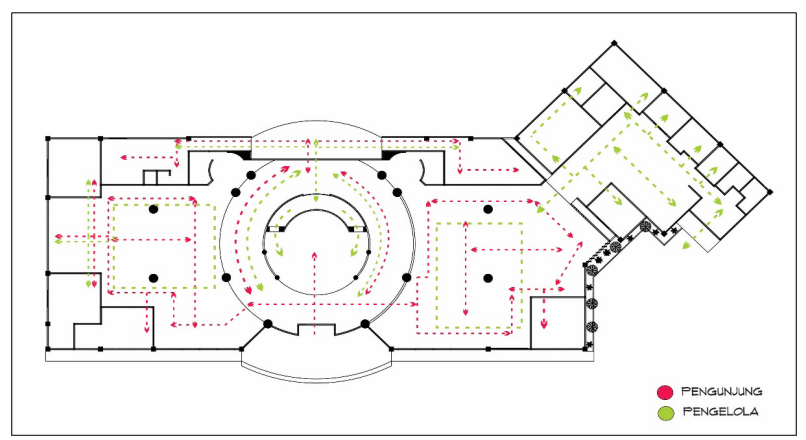

Gambar 4. Sirkulasi

\section{Tema dan Gaya}

Bali adalah primadona pariwisata Indonesia yang sudah terkenal di seluruh dunia. Selain terkenal dengan keindahan alam terutama pantainya, Bali juga terkenal dengan kesenian dan budayanya yang unik dan menarik. Eksplorasi budaya Bali tidak akan pernah ada habisnya dan selalu menarik untuk di angkat, termasuk salah satunya yaitu pernikahan di Bali.

Pentingnya desain sebuah toko bridal adalah untuk membangun sebuah pengalaman berharga calon pengantin. Melalui perpaduan warna, penampilan yang menarik dan membuat suasana yang nyaman untuk calon pengantin dan para customer, sehingga mereka tidak memiliki masalah ketika menghabiskan waktu dan uang di bridal boutique ini. Kualitas produk yang dijual juga merupakan hal utama, produk eksklusif harus dikemas dengan baik agar nilai dari produk tersebut tetap baik. Secara psikologis, kesan yang ditampilkan di bridal boutique ini adalah tempat yang prestigious atau bergengsi sesuai dengan segmen pasar yakni kelas atas (high class), dimana ketika customer membeli produk atau gaun di bridal boutique bukan hanya terpenuhinya kebutuhan, namun juga meningkatnya pandangan kelas sosial terhadap mereka. 
Kebudayaan Bali merupakan kebudayaan yang berwajah natural dan berjiwa ritual. Jiwa ritual dipegaruhi oleh sistem religi Hindu yang datang dari India. Hal ini sangat mempengaruhi pembentukan elemen-elemen arsitekturnya. Setiap corak, pembentukan ruang, elemen dan ragam hias memiliki filosofi yang pada hakikatnya merupakan bentuk peghormatan dan penghargaan terhadap alam dan Pencipta. ${ }^{1}$

Perancangan interior Bridal Boutique di Bali mengusung tema "La Femme Balinaise est Magnifique” atau dalam Bahasa Indonesia berarti Kecantikan Perempuan Bali Wanita bali disini dikonotasikan sebagai wanita bali yang sedang memakai pakaian pernikahan adat. Penerapan arsitektur bali, ragam hias bali, hingga material khas bali dihadirkan guna menambah cita dan rasa ruang yang di rancang.

\section{a. Karakteristik dan Kebudayaan Bali}

Tri angga dan tri hita karana merupakan filosofi dasar atau filosofi utama yang menjadi titik acuan arsitektur tradisional Bali. Tri Angga merupakan konsep keseimbangan kosmologis yang dalam perinsipnya terdapat tiga tatanan nilai tentang hubungan alam selaku "wadah" dan manusia sebagai "pegisi". Tata (hierarki) ini memperlihatkan gradasi tingkatan dengan spirit ketuhanan berada pada tingkat paling tinggi. Secara aplikatif filosofi tri angga dapat dilihat dari gestur bangunan yang memperlihatkan tiga tingkatan, yaitu kepala-badan-kaki. ${ }^{2}$

Dari filosfi tri angga kemudian berkembang konsep lain yakni konsep tri hita karana. Dalam konsep tri hita karana terdapat tiga unsur penghubung antara alam dan manusia untuk membentuk kesempurnaan hidup, yaitu jiwa, raga dan tenaga. Tiga sumber kebahagiaan tersebut akan tercipta dengan memperhatikan

\footnotetext{
1 Arrafiani, Griya Kreasi Rumah Etnik Bali. Griya Kreasi, 2012. Hal. 8

2 Arrafiani, Griya Kreasi Rumah Etnik Bali. Griya Kreasi, 2012. Hal. 15
}

keharmonisan hubungan antara manusia dengan pencipta, manusia dengan manusia, manusia dengan alam. ${ }^{3}$ Konsep tri angga dan tri hita karana yang akan di terapkan pada perancangan interior bridal boutique di Bali antara lain:

\section{1) Material}

Bahan yang digunakan dalam arsitektur Bali selalu berusaha meilih bahan-bahan dari alam sekitarnya, sebagai bentuk keserasian hubungan antara manusia dengan alam.

a) Kayu

Di Bali hampir semua typologi bangunan menggunakan kayu, untuk tiang, kerangka atap, ukiran sehingga secara tradisional kayu menjadi bahan utama. Penggunaan kayu dalam sistem konstruksi arsitektur rumah Bali mempertimbangkan konsep tri angga (hierarki). Jenis kayu yang digunakan berbeda dengan yang lain sesuai hierarki ruang tersebut.

1. Area Utama atau tempat yang memiliki kedudukan paling tinggi seperti tempat ibadah biasanya menggunakan kayu cendana dan cempaka karena dianggap suci. Kayu cendana dan cempaka digunakan sebagai pelinggih yang dianggap sebagai peragan Bhatara Siwa.

2. Area Madya (Bale/Perumahan) biasanya menggunakan kayu jati, kayu nangka, Sentul. Pengguaan material kayu tersebut karena memiliki struktur yang kuat, awet dan tahan rayap.

3. Area Nista (dapur) menggunakan kayu wangkal, juwet, klampuak, karena merupakan bahan yang kuat sebagai konstruksi.

b) Batu Alam

Batu alam adalah material yang selalu digunakan dalam arsitektur tradisional Bali,

3 Arrafiani, Griya Kreasi Rumah Etnik Bali. Griya Kreasi, 2012. Hal. 17 
seperti bata merah, batu paras, batu andesit, puhu. Bata merah memiliki karakteristik yang sedikit berbeda dengan bata merah pada kebanyakan daerah lain di Indonesia. Tanah liat di Bali cenderung padat dan berwarna lebih merah sehingga warnanya solid dan halus.

\section{2) Ragam Hias (Ornamen)}

Arsitektur Tradisional Bali merupakan perwujudan keindahan manusia dan alamnya yang mengeras kedalam bentuk-bentuk bangunan dengan ragam hias yang dikenakannya. Benda-benda alam yang diterjemahkan kedalam bentuk-bentuk ragam hias, tumbuh-tumbuhan, binatang unsur alam, nilai-nilai agama dan kepercayaan disarikan kedalam suatu perwujudan keindahan yang harmonis. ${ }^{4}$ Perancangan Interior Bridal Boutique di Bali ini perancang menggunakan ragam hias tumbuh-tumbuhan sebagai penggambaran hubungan antara manusia dengan alam pada konsep tri hita karana.

Ragam hias bunga-bunga atau ornament merupakan stilasi bentuk-bentuk tanaman. Bentuk ukiran semacam ini sangat banyak dijumpai dalam perabot rumah tangga seperti kursi, tempat tidur, almari, meja hias dan masih banyak yang lainnya. ${ }^{5}$ Ragam hias seperti ini disebut sebagai pepatran.

Pepatran atau patra merupakan salah satu bentuk ornament flora dari Bali. Pepatran banyak didasarkan pada bentuk-bentuk keindahan flora menamai pepatran dengan jenis flora yang di wujudkan. Ragam hias yang tergolong pepatran merupakan pola yang berkembang. ${ }^{6}$ Penggunaan ragam hias flora, fauna dan alam di Bali banyak di gunakan pada bangunan tempat tinggal, tempat musyawarah, tempat pemujaan

4 Nyoman, I Suendi. Arsitektur Tradisional Daerah Bali. Pustaka Cakra, 2005. Hal 127

5 Soegeng Toekio, M. Mengenal ragam hias Indonesia. Angkasa, 1987. Hal 85

6 Nyoman, I Suendi. Arsitektur Tradisional Daerah Bali. Pustaka Cakra, 2005. Hal 130 (pura).

Penggunaan ornament atau ragam hias Bali sebagai dekoratif pada elemen pembentuk ruang maupun elemen pengisi ruang, seperti pada pintu, pillar maupun furniture. Karakter warna menjadi faktor pendukung penciptaan karakter ruang, warna dominan emas akan memunculkan warna pakaian tradisional Bali pada interiornya.

\section{b. Tata Rias Pengantin Bali}

Tata rias pengantin terdiri dari riasan wajah, rambut dan pakaian, dijelaskan sebagai berikut; ${ }^{7}$

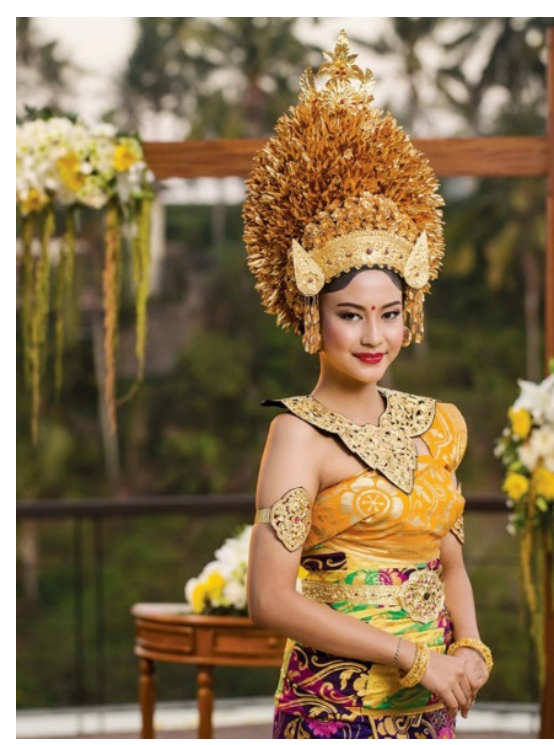

Gambar 5. Pakaian Adat Pernikahan Bali

1) Tata rias wajah pengantin wanita meliputi hiasan dahi Srinatha, menghias alis, menghias mata, menghias hidung, dan menghias bibir. Warna yang biasa digunakan dalam pengantin Bali adalah warna-warna cerah seperti warna emas, oranye, atau kuning yang melambangkan kejayaan, dan kemakmuran. Pada riasan mata pengantin Bali menghindari penggunaan eyeshad-

7 Skripsi Ni Putu Delia Wulansari, Bentuk, Fungsi Dan Makna Tata Rias Dan Prosesi Upacara Perkawinan Bali Agung Di Bali, Universitas Negeri Surabaya, 2015. 
ow warna merah, karena menurut kepercayaan masyarakat warna merah memiliki arti negatif (kemarahan).

2) Penataan rambut pengantin putri menggunakan pusungan dan hiasan semi. Adapun beberapa aksesoris antara lain : petites tajuk dan bunga sasak, bunga bancangan dan puspa limbo, gelung agung, sandat emas, kap emas, garuda mungkur, dan kompyong.

a) Gelung Agung terinspirasi dari gunung yang ditumbuhi oleh bunga yang indah dan harum. Gelung Agung memiliki makna keagungan / kebesaran. Pada hiasan gelung agung memakai bunga sandat dan bunga cempaka putih dan kuning melambangkan Tri Sakti (Brahma, Wisnu, Siwa) berkaitan dengan keagamaan, Tri Sakti sebagai Dewa Kahyangan tiga yang bertugas sebagai pencipta, pemelihara, dan pelebur. Tata letak bunga cempaka putih bagian terluar, cempaka kuning bagian tengah, dan sandat bagian dalam sudah pakem dan tidak bisa dirubah.

b) Sandat emas, Bunga Sandat Emas, seperti pepatah orang Bali mengatakan, "oh ibungan sandat selayu-layune miyik" yang artinya oh bunga kenanga walaupun dia telah layu namun tetap harum. Pengantin diibaratkan sebagai bunga kenanga, yang diharapkan nantinya sampai kapanpun, dalam keadaan apapun akan tetap menjadi pribadi yang baik dalam kebenaran. Hiasan bunga sandat ini dibentuk menyerupai segitiga memiliki ujung mengarah ke atas, mengarah ke angkasa atau ke Tuhan.

3) Busana dan aksesoris pernikahan tradisional Bali terdiri dari : tapih, wastra perada, sabuk perada, cerik prada, badong, gelang kana, gelang naga satru, pending, subeng, dan cincin. Dalam adat berbusana Perkawinan Bali menggunakan dua lapis kain. Inti dari makna yang terkandung didalam tapih adalah untuk menghindari perempuan dari hal-hal yang tidak diinginkan. Motif yang digunakan pada kain untuk pakaian adalah motif bunga-bunga atau flora yang memilki makna ketabahan, tahan lahir bathin, ibarat keharuman bunga.

4) Bunga KambojaBunga Kamboja dan masyarakat Bali memiliki keterkaitan yang sangat erat dan tidak dapat dipisahkan. Kamboja tidak hanya digunakan sebagai salah satu bunga yang dianggap sakral yaitu untuk sesembahan atau pemujaan, namun juga dalam kehidupan sehari-hari. Bunga kamboja memiliki dua peranan penting dalam agama Hindu, yakni sebagai simbol Dewa Siwa dan sebagai sarana sembahyang semata. Sebagai simbol Dewa Siwa. Bunga kamboja juga digunakan untuk menunjukkan kesucian hati saat memuja Sang Hyang Widi Wasa serta sinar suci-Nya, para leluhur

dan para Rsi (guru dalam bidang spiritual) ${ }^{8}$

Berdasarkan filosofi Hindu, pohon kamboja di Bali berbunga pada sasih kapat (bulan purnama ke empat) yang merupakan bulan baik. Bunga tersebut juga dianggap sebagai "sari alam",jadi bunga kamboja dapat diartikan sebgai sari alam yang membawa pencerahan dan sarisari kebaikan

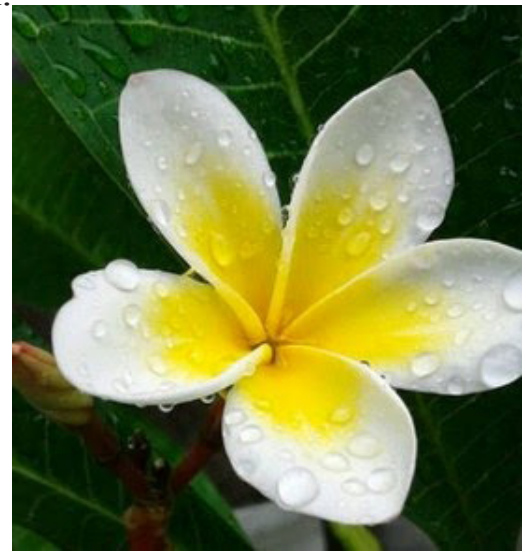

8 http://panduanwisata.id/2014/11/11/makna-bunga-kamboja-dalam-upacara-umat-hindu/ diakses pada tanggal 19 November 2017 pukul 21:19 WIB 


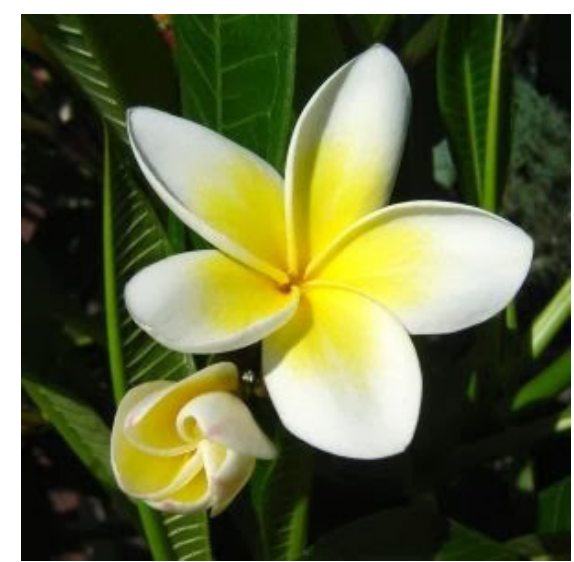

Gambar 6. Bunga Kamboja Bali

Karakter Interior yang ingin ditampilkan adalah karakter untuk memindahkan ide perancangan diatas ke dalam sebuah desain interior. Karakter yang dimaksud adalah hangat, nyaman, romantis, elegan dan mampu menghadirkan unsur keragaman Budaya Bali pada interior bridal boutique. Karakter Interior yang jugs akan dibentuk melalui beberapa bentuk dari stilasi bunga kamboja kedalam elemen-elemen pembentuk ruang maupun elemen pengisi ruang. Berikut adalah trasformasi bentuk dari pakaian pernikahan adat bali:

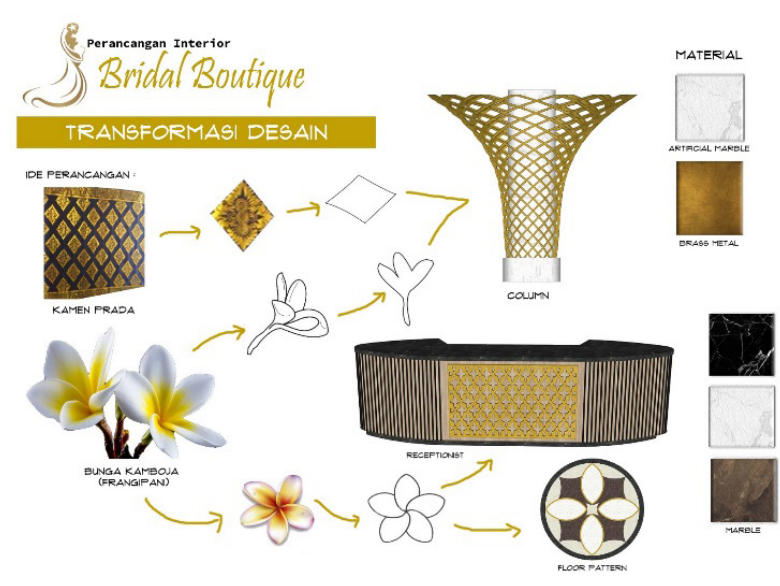

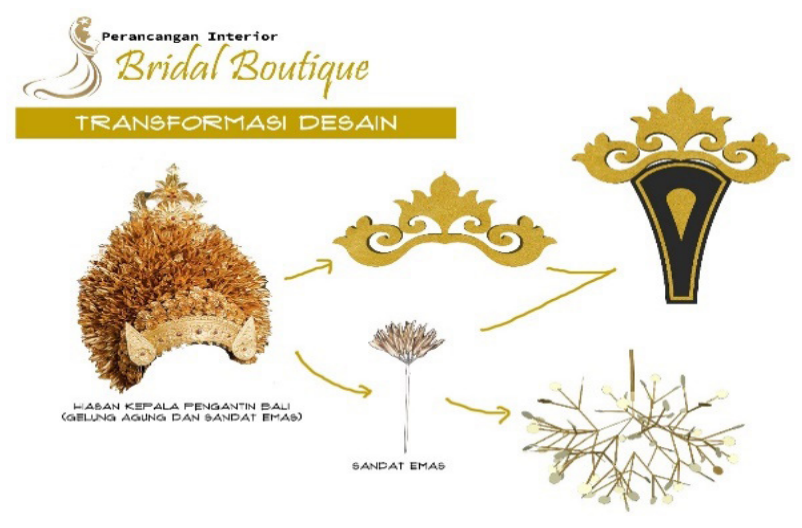

Gambar 7. Transformasi Desain

\section{Layout}

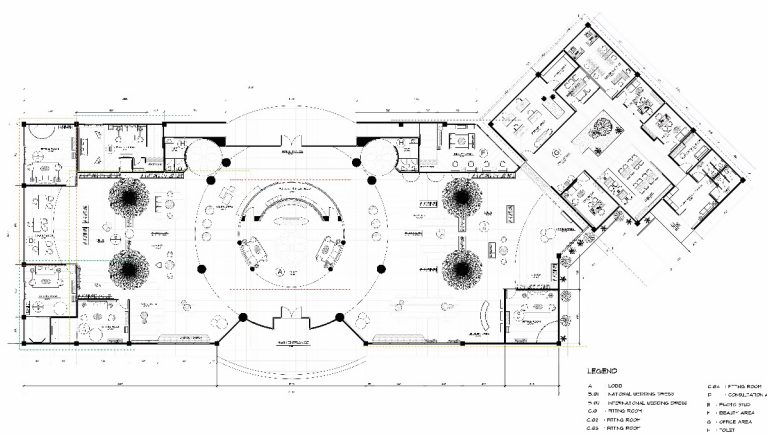

Gambar 8. Layout

\section{Hasil Desain}

Berdasarkan hasil data lapangan dan data literatur terdapat beberapa ruang lingkup garap yang meliputi ;

\section{a. Lobby Area}

Merupakan main entrance yang meliputi resepsionis dan ruang tunggu. Resepsionis berfungsi sebagai tempat untuk mendapatkan informasi. Ruang tunggu sebagai tempat duduk pengunjung. Berdasarkan fungsinya area lobby mengutamakan kenyamanan dan kemudahan konsumen mendapatkan informasi mengenai produk yang di tawarkan. 

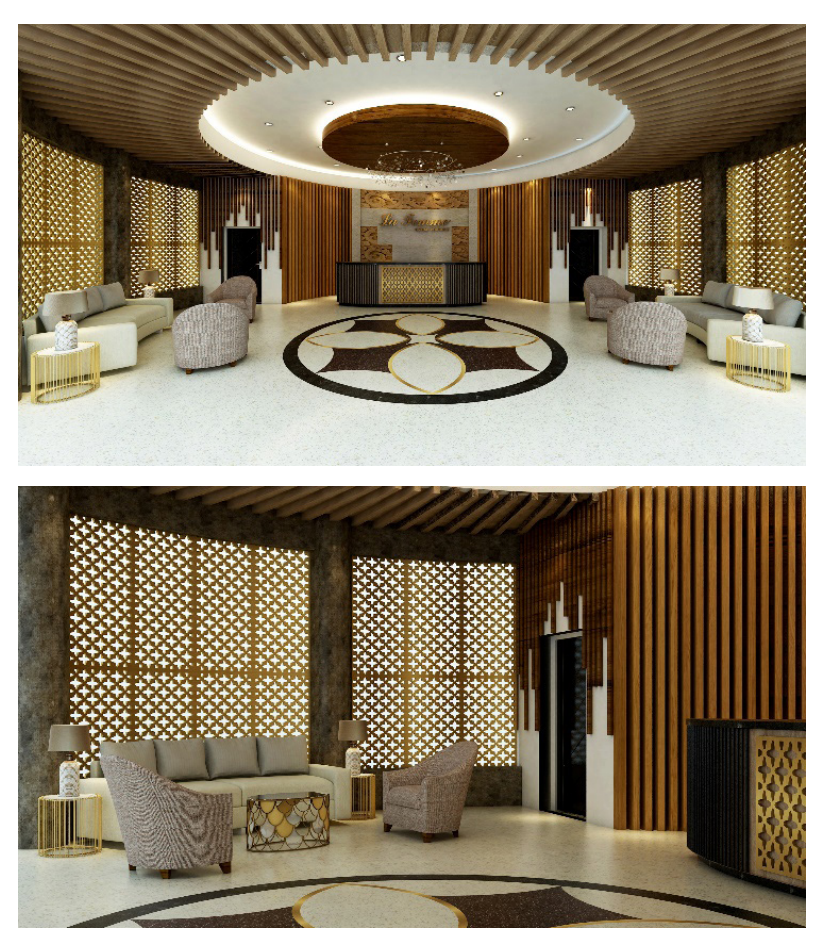

Gambar 9. Area Lobby

\section{b. Retail Area}

Retail area adalah area pajang produk yang terdiri dari wedding gown, tuxedo, kid's gown and tuxedo,shoes, jewelry, veil, invitation card, souvenirs and accessories. Berdasarkan fungsinya retail area merupakan area retail yang mengutamakan kemudahan konsumen dalam memilih dan membeli barang, pemajangan barang yang eye catching, pengelompokan area, dan kemudahan akses bagi konsumen maupun staff.

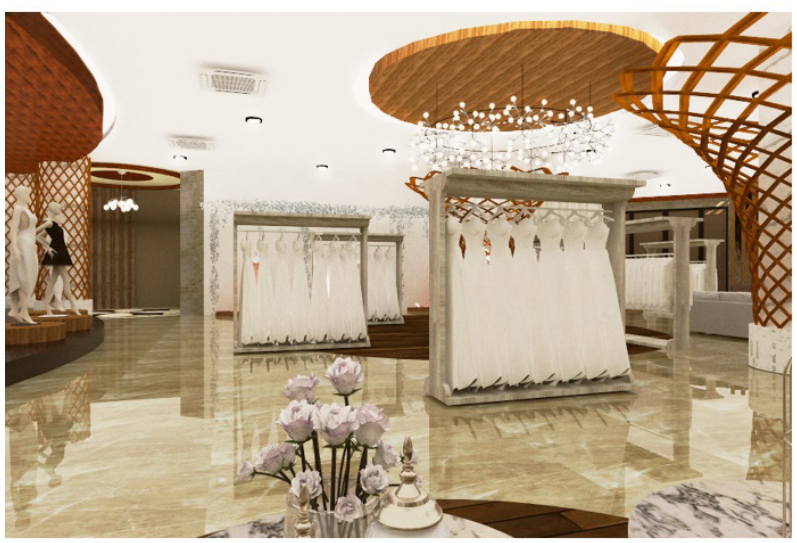

Gambar 10. National Weding Gown Area

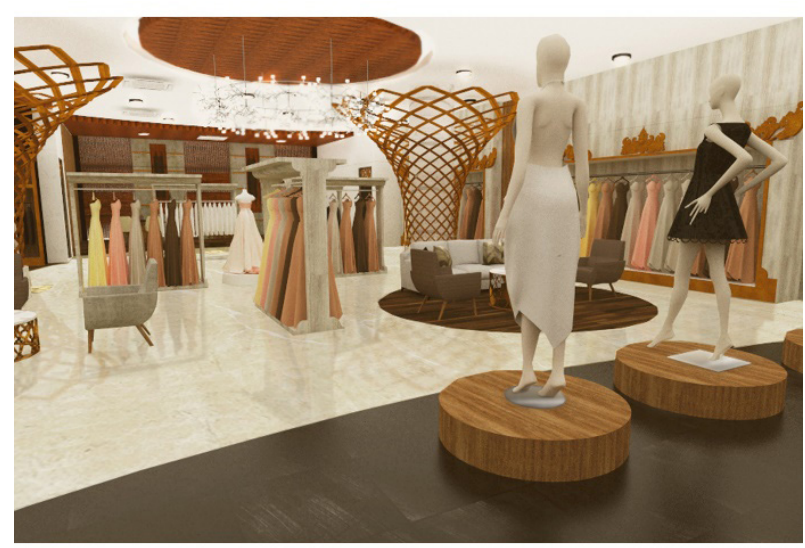

Gambar 11. International Weding Gown Area

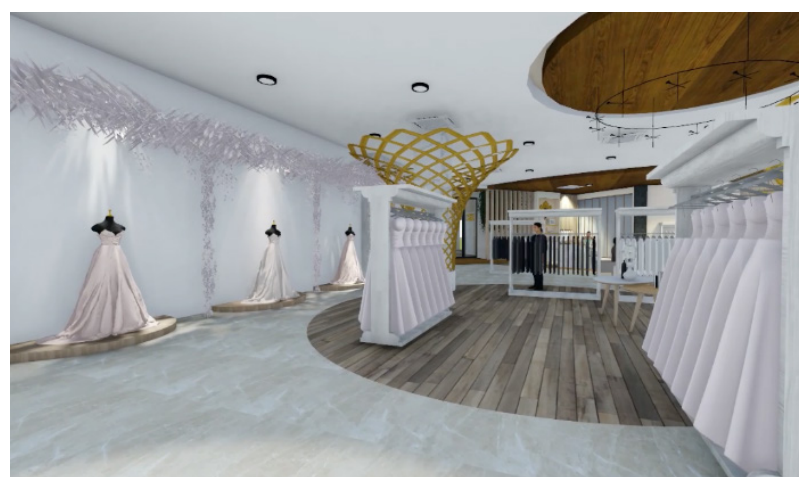

Gambar 12. International Weding Gown Area

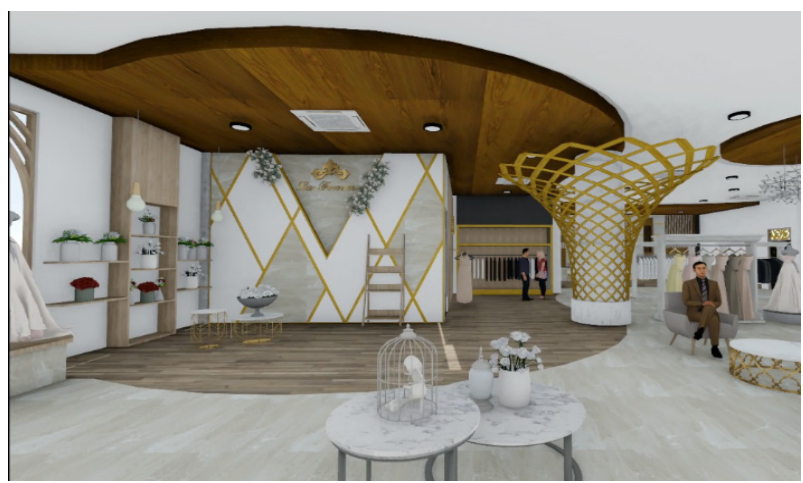

Gambar 13. Flower Bouquet Area

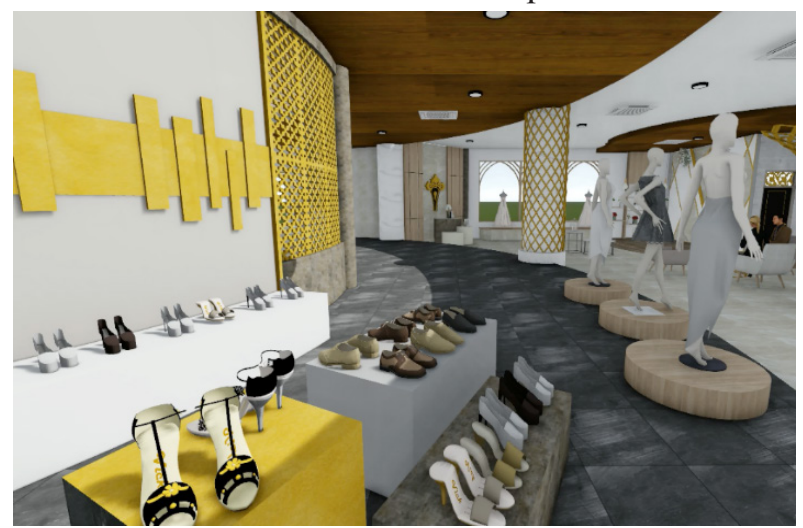

Gambar 14. Shoes Area 


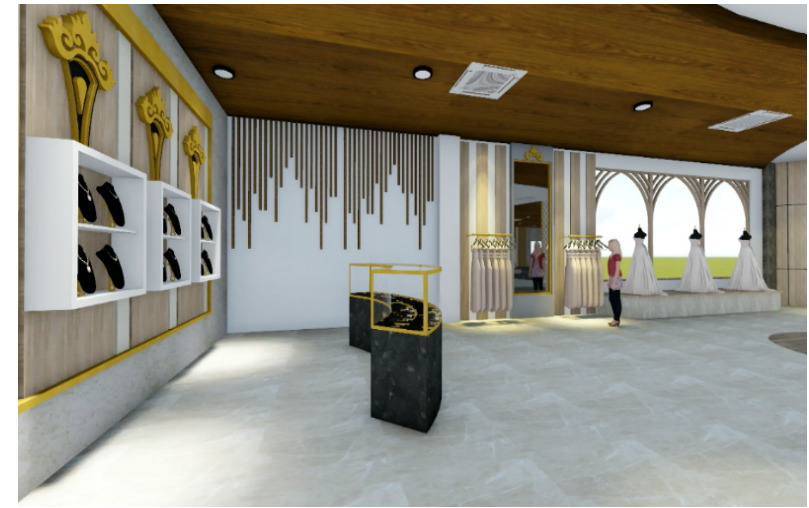

Gambar 15. JewelryArea

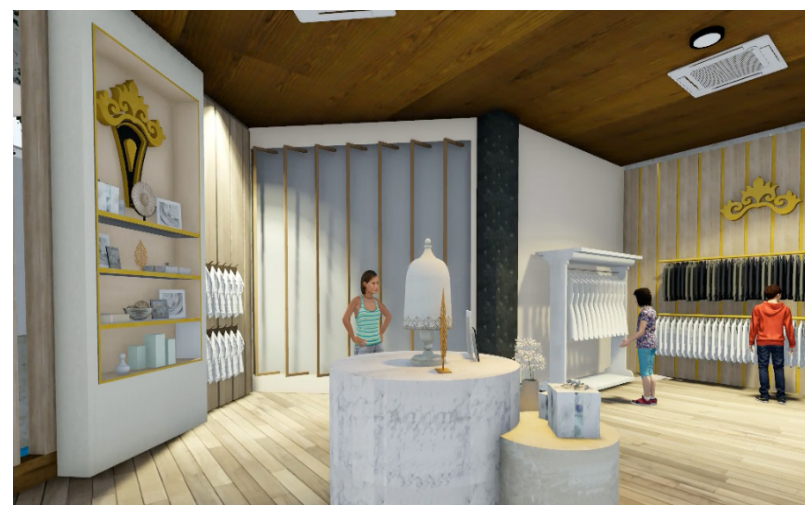

Gambar 16. Veil, invitation card, souvenirs dan Kid's area.

\section{c. Fitting Room}

Terdiri atas ruang pas dan area tunggu. Ruang pas digunakan untuk mencoba pakaian pengantin yang telah dipilih dan sebagai tempat ukur badan untuk mendapatkan pakaian yang sesuai bentuk tubuh mereka.. Area tunggu yang digunakan kerabat atau pasangan calon pengantin ketika menunggu pasangannya mecoba pakaian pengantin di dalam ruang.

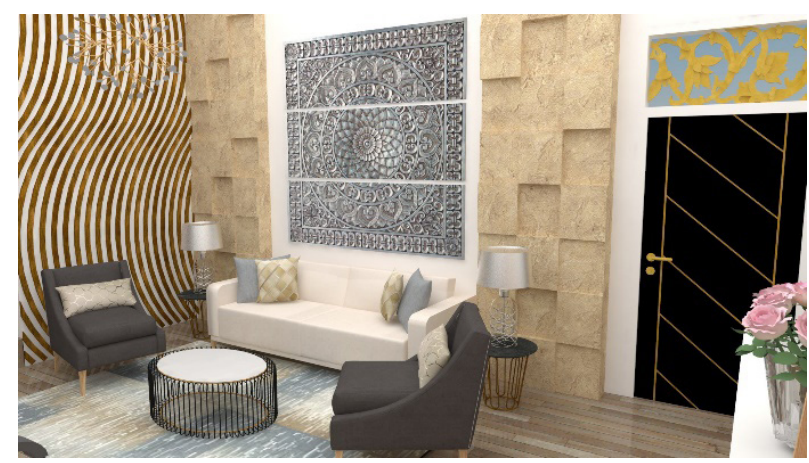

Gambar 17. Area Tunggu Fitting Room d. Beauty Area

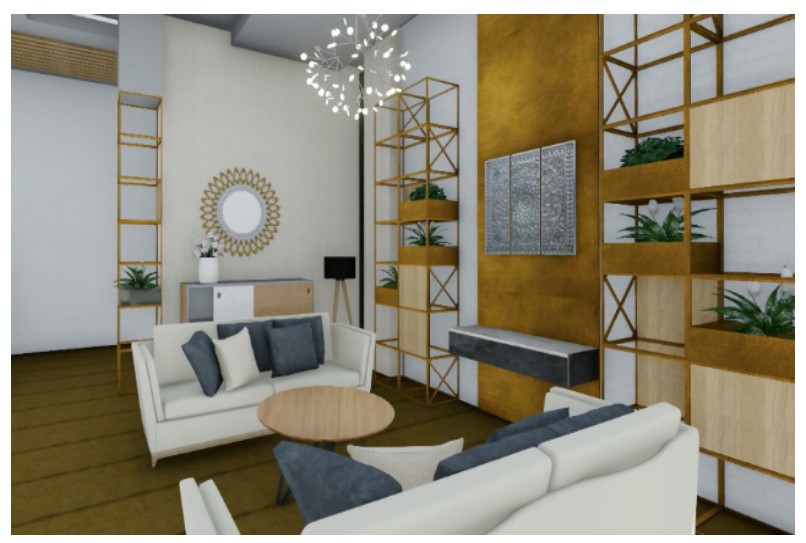

Gambar 18. Makeup area

Beauty area atau area kecantikan merupakan area yang terdiri dari hair do and make up. Area ini berfungsi sebagai tempat para calon pengantin maupun keluarga yang melakukan rias wajah dan rambut. Area ini terdiri dari dressing table dan rak - rak penyimpanan peralatan rias. Berdasarkan fungsinya area ini mengutamakan kenyamanan, efisiensi dan keamanan bagi konsumen maupun staff.

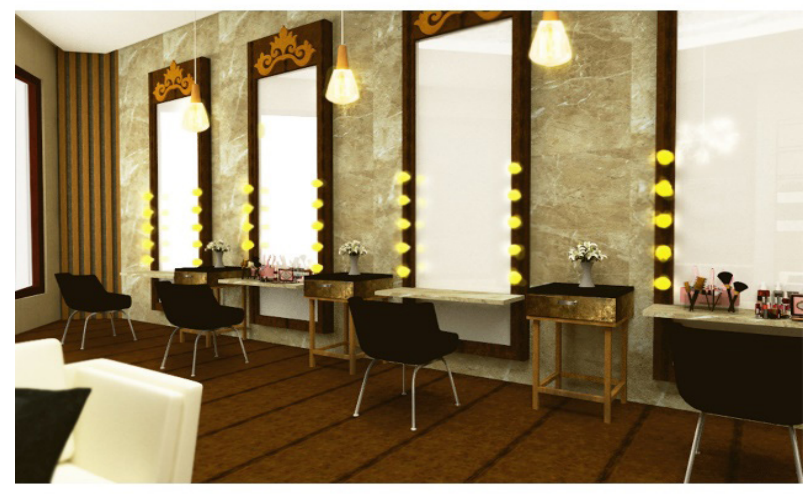

Gambar 19. Area Tunggu Beauty Area

\section{e. Consultation Area}

Area konsultasi merupakan tempat bagi para konsumen untuk melakukan konsultasi desain dengan fashion designer / fashion stylist. Berdasarkan fungsi tersebut area konsultasi mengutamakan efesiensi, kenyamanan, keamanan dan kemudahan bagi staff dan konsumen. 


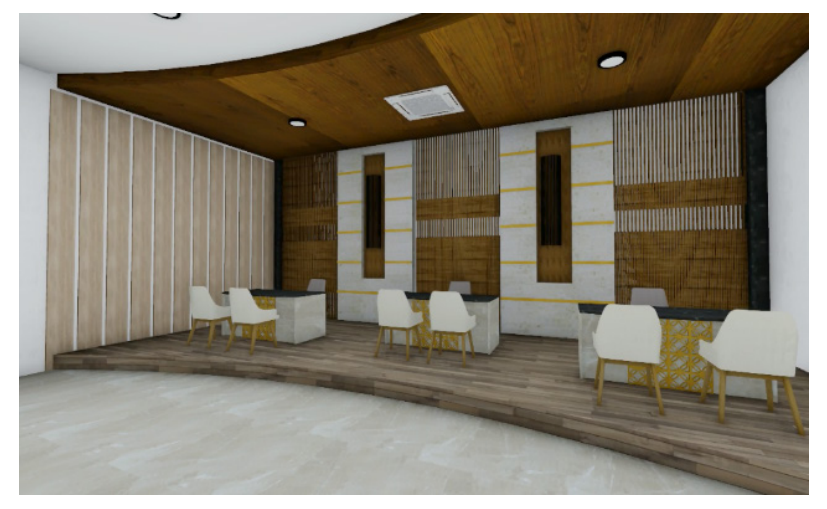

Gambar 20. Consultation Area

\section{f. Photo Studio}

Studio foto merupakan area yang digunakan untuk pengambilan gambar indoor untuk kebutuhan pre-wedding maupun foto lainnya.

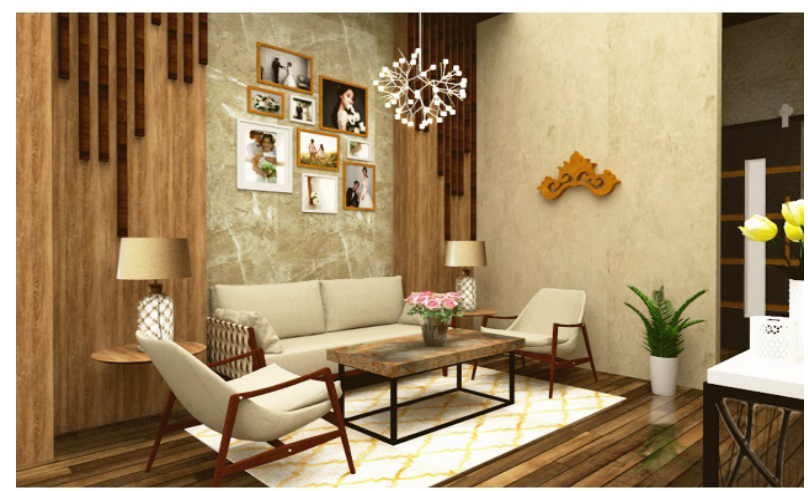

Gambar 21. Photo Studio Area

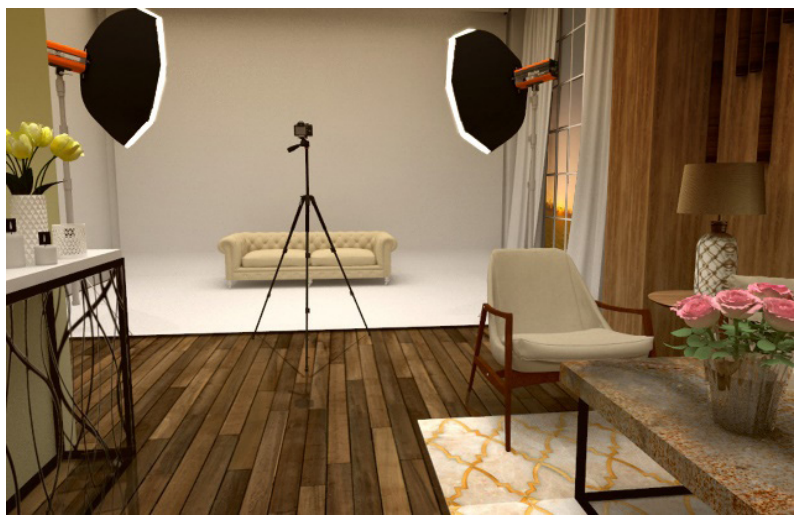

Gambar 22. Area Tunggu Photo Studio g. Office Area

Office area berupa ruang kerja, ruang pertemuan dan area pantry untuk para staff. Berdasar fungsinya area ini mengutamakan efisiensi, kenyamanan dan produktifitas bagi staff.

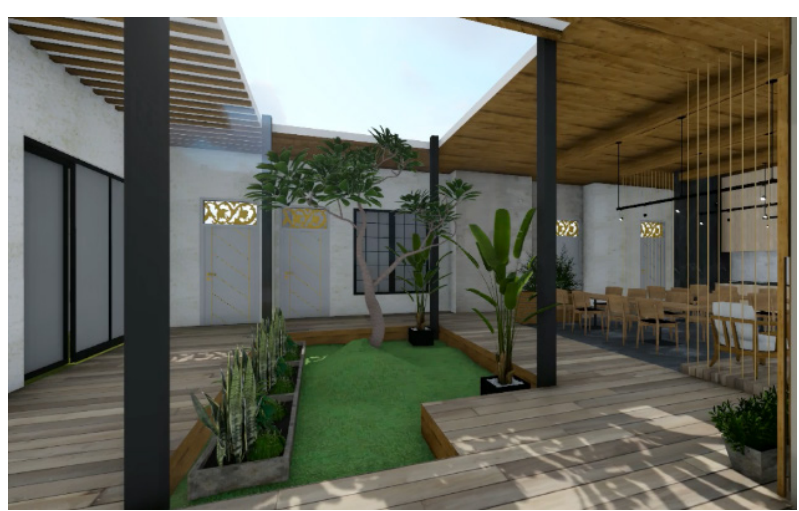

Gambar 23. Open Space pada Office area

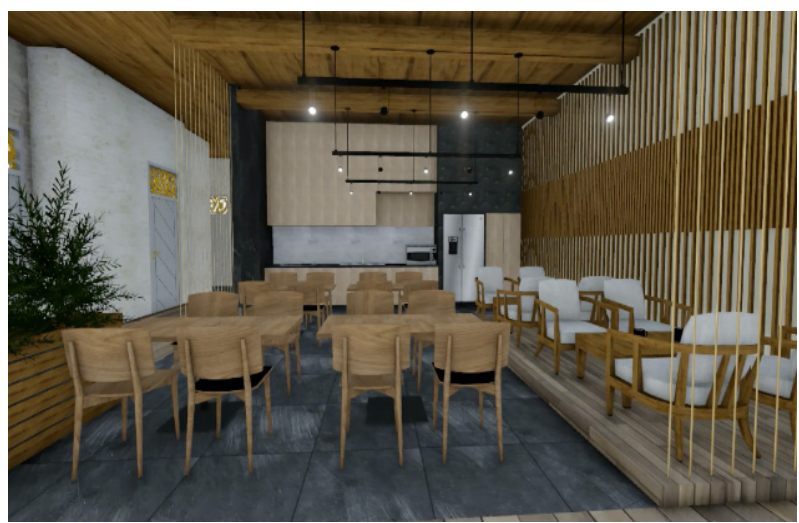

Gambar 24. Pantry pada Office area.

\section{Sistem Pencahayaan}

Pencahayaan pada perancangan interior bridal boutique di Bali menggunakan cahaya alami dan cahaya buatan. Cahaya buatan diperoleh dari lampu general lighting dan accent lighting. 


\begin{tabular}{|c|c|c|}
\hline $\begin{array}{c}\text { Jenis } \\
\text { Lampu }\end{array}$ & Spesifikasi & Gambar \\
\hline $\begin{array}{l}\text { General } \\
\text { Lighting }\end{array}$ & $\begin{array}{l}\text { Jenis Lampu: } \\
\text { LED } \\
\text { Produk : Philips, } \\
\text { putih sejuk } \\
\text { 40W (80W } \\
\text { CFL), E40 }\end{array}$ & \\
\hline $\begin{array}{l}\text { General } \\
\text { Lighting }\end{array}$ & $\begin{array}{l}\text { Jenis Lampu: } \\
\text { LED } \\
\text { Produk : Philips, } \\
\text { Cool daylight } \\
\text { 18W (130W), Kap } \\
\text { E27 } \\
220-240 \mathrm{~V}\end{array}$ & \\
\hline $\begin{array}{l}\mathrm{S} p \text { o t } \\
\text { Light }\end{array}$ & $\begin{array}{l}\text { LED ceiling } \\
\text { spotlight fixture } \\
\text { with two spots } \\
562424816 . \\
\text { Ex : Philips } \\
\end{array}$ & \\
\hline $\begin{array}{l}\text { Strip Light } \\
\text { LED }\end{array}$ & $\begin{array}{l}\text { Jenis lampu : LED } \\
\text { tape flexible } \\
\text { Produk : Philips, } \\
\text { Warm White }\end{array}$ & \\
\hline
\end{tabular}

Tabel 01. Sistem Pencahayaan

\section{Sistem Penghawaan}

Perancangan desain interior bridal boutique di Bali, penghawaan akan banyak menggunakan penghawaan buatan karena wilayah Pulau Bali sangat panas, sehingga demi kenyamanan lebih baik menggunakan penghawaan buatan. Berikut adalah table yang menjelaskan spesifikasi air conditioner yang digunakan dalam perancangan desain interior bridal boutique di Bali;

\begin{tabular}{|l|l|l|}
\hline \multicolumn{1}{|c|}{ Nama } & \multicolumn{1}{|c|}{ Spesifikasi } & Gambar \\
\hline $\begin{array}{l}\text { Central Air } \\
\text { conditioner }\end{array}$ & $\begin{array}{l}\text { Ceiling Mounted Air } \\
\text { Conditioners } \\
4.2 / 4.5 \mathrm{~kW} \text { cooling } \\
/ \text { heating capacity } \\
\text { Ex. Mitsubishi } \\
\text { Electric }\end{array}$ \\
\hline $\begin{array}{l}\text { Split Air con- } \\
\text { ditioner }\end{array}$ & $\begin{array}{l}\text { Split air conditioner } \\
\text { dengan energy sav- } \\
\text { ing. JS-Q18NPXA } \\
\text { Ex : LG }\end{array}$ \\
\hline Exhaust fan & $\begin{array}{l}\text { Ducted exhaust fan. } \\
\text { Diameter fan } 15 \mathrm{~cm} \\
\text { Ex : Panasonic }\end{array}$ \\
\hline
\end{tabular}

Tabel 02. Sistem Penghawaan

\section{Sistem Kenyamanan}

System keamanan berperan dalam meningkatkan keamanan dan kenyamanan bagi pennggunanya. Adanya sistem keamanan adalah untuk mengantisipasi sesuatu yang tidak diinginkan. Berikut adalah table yang menjelaskan spesifikasi sistem keamanan yang digunakan dalam perancangan bridal boutique di Bali;

\begin{tabular}{|l|l|l|}
\hline Nama & \multicolumn{1}{|c|}{ Spesifikasi } & Gambar \\
\hline $\begin{array}{l}\text { Smoke } \\
\text { Detector }\end{array}$ & $\begin{array}{l}\text { Smart smoke detector } \\
\text { yang dapat diinte- } \\
\text { grasikan dengan hand- } \\
\text { phone pengguna, dual } \\
\text { sensor, voice detector, } \\
\text { dan dilengkapi dengan } \\
\text { lampu LED. Ex : NEST }\end{array}$ & \\
\hline CCTV & $\begin{array}{l}\text { Nest Cam Outdoor } \\
\text { Security Camera adalah } \\
\text { kamera pengaman yang } \\
\text { memiliki angel 130 }, \\
\text { waterproof serta dapat } \\
\text { diintegrasikan dengan } \\
\text { smartphone. } \\
\text { Ex : NEST }\end{array}$ \\
\hline
\end{tabular}




\begin{tabular}{|c|c|c|}
\hline $\begin{array}{l}\text { Fire } \\
\text { Sprinkle }\end{array}$ & $\begin{array}{l}\text { Fire sprinkle } \\
\text { Tekanan Air: } 175 \mathrm{PSI} \\
(1.2 \mathrm{Mpa}) \text { Suhu : } 74^{\circ} \mathrm{C}- \\
100^{\circ} \mathrm{C} \text {. Rentang panjang } \\
\text { semprotan : } 70-180 \mathrm{~cm} . \\
\text { Ex : TPMCSteel }\end{array}$ & 7 \\
\hline $\begin{array}{l}\text { Fire ex- } \\
\text { tinguish- } \\
\text { er }\end{array}$ & $\begin{array}{l}\text { Handy Fire extinguish- } \\
\text { er pemadam api porta- } \\
\text { bel yang dapat mengelu- } \\
\text { arkan air, busa, gas, dan } \\
\text { media lainnya. Disharge } \\
\text { time : } 8 \text {-12 seconds Dis- } \\
\text { charge range : } 182-243 \\
\text { cm } \\
\text { Pressure : } 100 \text { psi } \\
\text { Ex : Kidde }\end{array}$ & \\
\hline
\end{tabular}

Tabel 03. Sistem Keamanan

\section{Infografis (Sign System)}

Sign System adalah rangkaian representasi visual dan simbol grafik yang bertujuan sebagai media interaksi manusia dengan ruang publik. Sign system harus mempunyai fungsi yang jelas dan efisien. Sign system dapat digunakan juga untuk kepentingan lalu lintas, petunjuk arah di area publik, keselamatan, kepentingan komersial seperti promosi produk; tempat usaha;dan hal lainnya. Pembuatan sign system juga memilki kriteria tersendiri. kriteria dari sign system yaitu:

a. mudah dipahami

b. mudah di baca

c. penempatanya benar

Berikut adalah tabel sign system dalam perancangan interior bridal boutique di Bali;

\begin{tabular}{|c|c|}
\hline sign system & Keterangan \\
\hline$\dot{H} \mid \dot{\mid l}$ & $\begin{array}{l}\text { Papan petunjuk lokasi toi- } \\
\text { let }\end{array}$ \\
\hline wc & \\
\hline
\end{tabular}

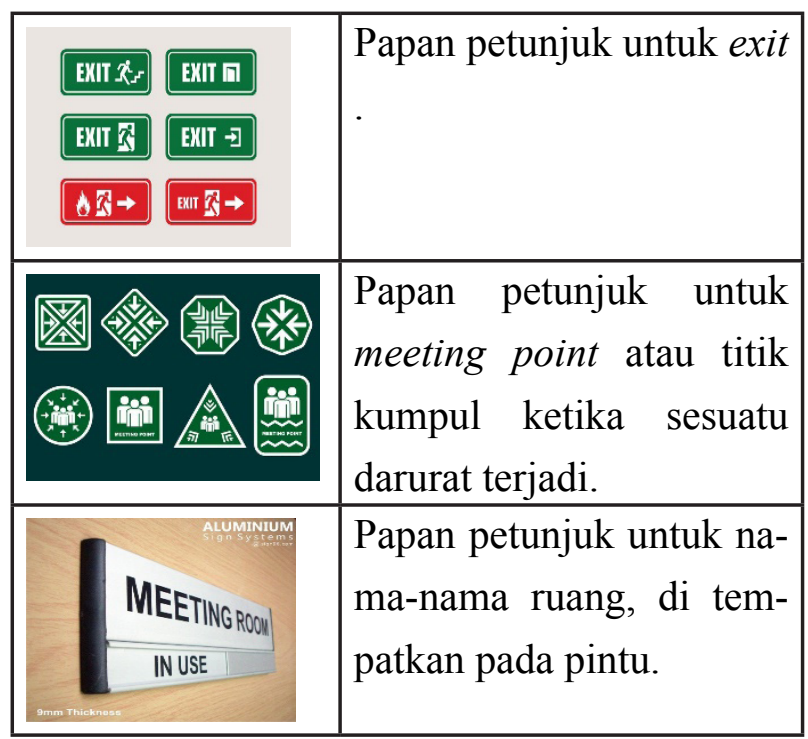

Tabel 04. Sign System

\section{SIMPULAN}

Perancangan Interior bridal boutique di Bali adalah salah satu alternatif toko kebutuhan pernikahan di Bali. Bali yang notabene adalah tujuan wisata nomor satu di Indonesia menawarkan keindahan alam yang membuat pelancong tertarik untuk berlibur dan mengabadikan momen berharga mereka. Salah satunya banyak dari mereka melangsungkan foto pre-wedding maupun acara wedding party di pulau dewata.

Melihat kebutuhan tersebut perancang ingin memfasilitasi mereka yang membutuhkan segala keperluan pernikahan di satu tempat. Dimana terdapat fasilitas bridal gown, party gown, bridesmaid gown, children gown and suit, tuxedo, shoes, makeup and hair do, flower bouquet atau buket bunga, veil, gloves, asessoris seperti necklacle, earings dan crown, sovenir pernikahan, undangan pernikahan, konsultasi dengan desainer, make up dan hair do serta photography. Bridal boutique ini melayani perancangan gaun bergaya nasional maupun internasional.Tidak hanya itu, bridal boutique ini diharapkan menjadi pusat mode bridal yang berada di Bali maupun Indonesia. 
Perancangan interior Bridal Boutique di Bali mengusung tema "La Femme Balinaise est Magnifique” atau dalam Bahasa Indonesia berarti Kecantikan Perempuan Bali Wanita bali disini dikonotasikan sebagai wanita bali yang sedang memakai pakaian pernikahan adat. Perancangan ini menerapan arsitektur bali, ragam hias bali, hingga material khas bali. Penampilan yang menarik dan suasana yang nyaman membuat calon pengantin tidak memiliki masalah ketika menghabiskan waktu dan uang di bridal boutique ini. Secara psikologis, kesan yang ditampilkan di bridal boutique ini adalah tempat yang prestigious sesuai dengan segmen pasar yakni kelas atas (high class), dimana ketika customer membeli produk atau gaun di bridal boutique bukan hanya terpenuhinya kebutuhan, namun juga meningkatnya pandangan kelas sosial terhadap mereka.

\section{DAFTAR PUSTAKA}

Francis D.K. Ching.2011. Desain Interior Dengan Ilustrasi edisi kedua. Jakarta: Erlangga.

Jerusalem, Mohammad Adam.2012. Merintis dan Mengelola Bisnis Butik. Yogyakarta

Kartika, Dharsono Sony.2004. Pengantar Estetika. Bandung; Rekayasa Sains

Suendi, I Nyoman, I.2005. Arsitektur Tradisional Daerah Bali. Pustaka Cakra

Suptandar J. Pamudji. 1999. Pengantar Merencana Interior untuk Mahasiswa Desain dan Arsitektur. Jakarta: Djambatan

Sunarmi. 2008. Buku Pegangan Kuliah Metodologi Desain. Surakarta: STSI Surakarta.

Sunarmi. 2001. Ergonomi dan Aplikasinya pada Kriya. Surakarta: STSI Surakarta.

Widyatmoko, Agung.2006. Peluang Usaha. Jakarta

\section{Artikel}

Imelda Akmal. Tanpa tahun. Seri Rumah Ide: Cermin Interior, Edisi 9

\section{Laporan Tugas Akhir}

Ni Putu Delia Wulansari, Bentuk, Fungsi Dan Makna Tata Rias Dan Prosesi Upacara Perkawinan Bali Agung Di Bali, Karya Skripsi Universitas Negeri Surabaya, 2015. 